\title{
Intangible Assets Accounting in Vietnam: Perspectives of a Professional Accounting Group
}

\author{
Tran Thi Thuong, Nguyen Thi Thuy \& Hoang Thi Mai Anh \\ Faculty of Accounting and Business Management, Vietnam National University of \\ Agriculture Hanoi 131000, Vietnam
}

\begin{abstract}
This study focused on presenting the views of members of a professional accounting group about intangible assets accounting in Vietnam. This group consisted of 44 random interviewees who were auditors, lecturers, and banking staff, among others. Based on the results of this survey, the characteristics of the professional accounting group, including occupation, educational level, and work experience, etc., were collected. The accounting regulations for intangible assets in Vietnam in accordance with the guidelines of Vietnamese Accounting Standard (VAS) No. 04 (Intangible assets and other circulars) were then analyzed. Especially, these interviewees indicated three main obstacles of intangible assets accounting through this survey. First, the skills and knowledge of accounting staff are the most current weaknesses of intangible assets accounting. Following that, the slow integration of Vietnamese accounting regulations with the international accounting system for intangible assets is a difficult point. Lastly, the limited knowledge of managers and internal governance are weak points. Hence, to improve intangible assets accounting in Vietnam, the Ministry of Finance (MOF) should organize additional training courses or workshops to train accountants and managers based on the contents of International Accounting Standard (IAS) No. 38 for intangible assets and IAS 36 for the impairment of assets. In addition, small specialized discussions among accountants, lecturers, auditors, and others in one city should be encouraged to open accounting seminars/workshops. These gatherings would be a good way to share their accounting experience with each other and improve their knowledge of accounting.
\end{abstract}

\section{Keywords}

Intangible assets, Vietnam, accounting, professional accounting group

Received: February 19, 2021

Accepted: April 1, 2021

\section{Correspondence to} tranthithuong@vnua.edu.vn

\section{Introduction}

The international economy has transformed from an industrial base to a knowledge base with an increase in the services sector. 
Hence, intangible assets have become more important to enterprises and their owners (Liselotth \& Carolina, 2006). The total value of intangible capital accounts for $66.7 \%$ of the market value of publicly traded corporations (Hall, 2001). Moreover, economic development comes from not only the production of material goods but also the manipulation of intangible assets (Goldfinger, 1998). The World Bank asserted that the preponderant form of worldwide development is intangible capital. Therefore, the key to business outcomes can be linked to intangible asset investment.

According to the perspective of companies, a consensus emerged on the fact that intellectual capital/intangible assets are a multidimensional and wide concept, consisting of the combination of human, structural or organizational, and relational resources of the enterprise (The European Union, 2002). Most definitions acknowledge that human capital refers to the capacity of employees, namely, their knowledge, skills, experience, and abilities (Roslender \& Fincham, 2004; Becerra-Fernandez \& Sabherwal, 2010), and indicate that human capital is inseparable from it owners. Structural capital can be embodied as the backbone of the organization, including the organization's strategies, processes, and policies (Mention, 2012). Structural capital is owned by the enterprises, and therefore, it can be traded in the market. Relational capital is defined as the ability of an organization to interact with external stakeholders like customers, suppliers, and other relationships (Mention, 2012; The European Union, 2002). However, it is still difficult to visualize what intangible assets are and how to recognize intangible assets in enterprises. Thus, the appearance of International Accounting Standard (IAS) 38, which asserts that intangible assets are very necessary, and this standard was selected as an available tool to describe and recognize intangible assets. According to IAS 38, not all intangibles are recognized as intangible assets in the financial statement system in the viewpoint of accounting (Brand Finance, 2016; Derun, 2013). The reason given is that it is impossible to evaluate and determine the future economic benefits of all kinds of intellectual capital (Derun, 2013). Hence, the intangible assets definition from accounting's perspective is a narrower concept than the intellectual capital definition from the company's perspective.

Thus, in Vietnam, to record and manage intangible assets, the Ministry of Finance (MOF) enacted Vietnamese Accounting Standard (VAS) 04 for intangible assets in 2001. This standard was promulgated in accordance with the first version of IAS 38 for intangible assets. However, Vietnam used a selective model from IAS 38, and VAS 04 has been neither updated nor amended for 18 years after promulgation. Therefore, accounting information about intangible assets has sometimes been incomplete and unclear, and did not satisfy the demands of users.

This study focuses on presenting the views of a professional accounting group about intangible assets accounting in Vietnam. This group sample consisted of 44 interviewees who were chosen randomly from auditors, lecturers, and banking staff, among others. Particularly, this study summarizes the accounting regulations for intangible assets in Vietnam following the guidelines of VAS 04 and other circulars. Simultaneously, this study discusses and analyzes obstacles and weak points in practicing intangible assets accounting in accordance with the views of the professional accounting group. Based on these views, this study will suggest some implications to innovate intangible assets accounting in Vietnam.

\section{Methodology}

Practical analysis was utilized to collect and analyze primary data from interviewees who were in accounting professions through interviewing. Specifically, the practical analysis consisted of four parts, as detailed in Figure 1.

This study employed a quantitative research method wherein a survey was done using questionnaires. A total of 44 interviewees were randomly selected as respondents of the study. The professional accounting group was defined as the auditors, lecturers or trainers, researchers, banking staff, consultants, and policymakers who have worked outside of Vietnamese enterprises. Consequently, with the random 


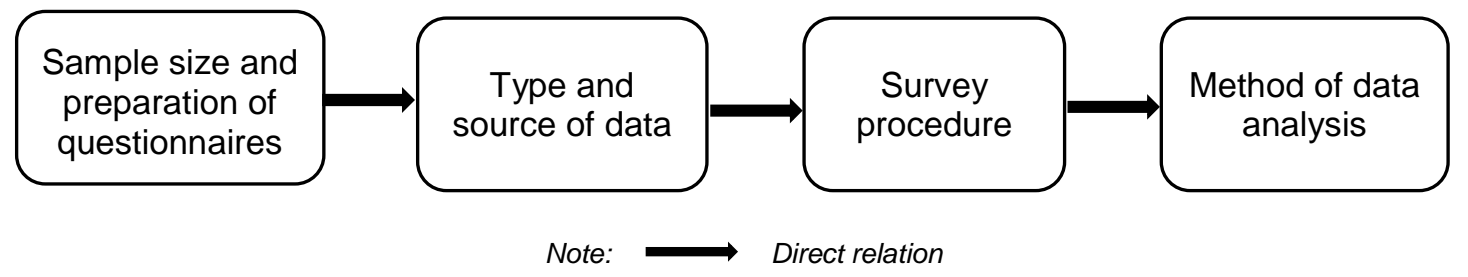

Figure 1. The concept of practical analysis

selection, the survey gathered 44 interviewees in total consisting of 21 auditors, 14 lecturers or trainers, and 9 others (banking staff, researchers, consultants, and policymakers), who were located in different offices in Vietnam.

The main list of questions for the questionnaires consisted of 21 questions that were divided into two separate sections in which the first section included two questions about the interviewee's general information (for example, work experience, accounting basic knowledge, and working skills), and the second section consisted of 19 questions about specific accounting information. Particularly, these 19 questions in the second section focused on gathering opinions about various intangible assets questions, such as, "In your opinion, how is the quality of intangible assets information that Vietnamese enterprises supplied on their financial statements? What are the obstacles to recognizing intangible assets in Vietnamese enterprises? How would you rate these obstacles to recognizing intangible assets in Vietnamese enterprises? What are the detailed obstacles of the legal framework for intangible assets accounting? What are the detailed obstacles of skills and knowledge of Vietnamese accountants when they practice intangible assets accounting? How do you assess the internal control system for intangible assets of enterprises? In your opinion, should Vietnam amend VAS 04 based on the latest version of IAS 38? In your opinion, which accounting model of IAS 38 should Vietnamese enterprises apply for intangible assets accounting?" In addition, each question was often divided into several layers including a main question and sub-questions. However, the subquestion list was only used if the information provided when answering the main question was not a satisfactory expectation (such as when the information gathered needed more details). The primary data was gathered through a face-to-face interview. Then, descriptive statistics were used to analyze the primary data collected from the survey.

In addition, this study used a five-point Likert scale to assess the identified obstacles of intangible assets accounting in Vietnamese enterprises based on the perspectives of the professional accounting group. Rating assessment options used in the questionnaires were $\mathrm{A} 0$ - not at all serious, A1 - slightly serious, A2 somewhat serious, A3 - moderately serious, and A4 - extremely serious. Simultaneously, this study also assessed "How often did the issue occur in intangible assets accounting?" through a five-point Likert scale ( 0 - Never, 1 - Rarely, 2 Sometimes, 3 - Often, and 4 - Always).

\section{Results and Discussion}

\section{Sociodemographic characteristics of the professional accounting group}

Table 1 describes the sociodemographic characteristics of the professional accounting group. For work experience, the highest level of experience among all the interviewees was 29 years, whereas the lowest was under 2 years. The most frequent experience timeframe was from 5 to 10 years, which made up $40.91 \%$ and was equivalent to 18 interviewees in total. Typically, interviewees worked at not just one position but also worked at other contemporary positions relevant to intangible assets. For example, one lecturer worked as a researcher as well as a consultant instead of working only as a trainer about intangible assets.

For educational level, $61.18 \%$ of the respondents (30/44 respondents) had a high educational level such as master's and doctoral degrees. Meanwhile, 14 interviewees $(31.82 \%$ interviewees) only had undergraduate degrees. 
Table 1. Sociodemographic characteristics of the professional accounting group

\begin{tabular}{|c|c|c|}
\hline Sociodemographic characteristics & Frequency $(\mathrm{N}=44)$ & Percentage (\%) \\
\hline \multicolumn{3}{|l|}{ 1. Occupation (Work position) } \\
\hline Auditor & 21 & 47.73 \\
\hline Researcher & 2 & 4.55 \\
\hline Lecturer or trainer & 14 & 31.82 \\
\hline Banking staff & 2 & 4.55 \\
\hline Consultant & 2 & 4.55 \\
\hline Policy maker & 3 & 6.82 \\
\hline Total & 44 & 100 \\
\hline \multicolumn{3}{|l|}{ 2. Work experience } \\
\hline Under 2 years & 4 & 9.09 \\
\hline From 2 to 5 years & 7 & 15.91 \\
\hline From 5 to 10 years & 18 & 40.91 \\
\hline From 10 to 15 years & 9 & 20.45 \\
\hline Over 15 years & 6 & 13.64 \\
\hline Total & 44 & 100 \\
\hline \multicolumn{3}{|l|}{ 3. Educational level } \\
\hline Undergraduate & 14 & 31.82 \\
\hline Post-graduate & 30 & 61.18 \\
\hline Total & 44 & 100 \\
\hline \multicolumn{3}{|l|}{ 4. Work area related to intangible assets } \\
\hline Auditing & 17 & 38.64 \\
\hline Research \& Training & 11 & 25.00 \\
\hline Consultant & 4 & 9.09 \\
\hline Auditing \& Consultant & 4 & 9.09 \\
\hline Research-training \& Consultant & 5 & 11.36 \\
\hline Officer for policy making & 3 & 6.82 \\
\hline Total & 44 & 100 \\
\hline \multicolumn{3}{|l|}{ 5. The length of having a CPA license } \\
\hline 5.1. Does not have a CPA license & 20 & 45.45 \\
\hline 5.2. Has a CPA license & 24 & 54.55 \\
\hline - Under 2 years & 4 & 9.09 \\
\hline - From 2 to 5 years & 5 & 11.36 \\
\hline - From 5 to 10 years & 11 & 25.00 \\
\hline - From 10 to 15 years & 4 & 9.09 \\
\hline - Over 15 years & 0 & 0 \\
\hline Total & 44 & 100 \\
\hline
\end{tabular}

As such, the educational level of the interviewees in this group was good.

A Vietnamese Certified Public Accountant (CPA) license is a domestic certificate and a practicing certificate of auditors which is granted by the MOF. Only auditors who have a CPA license have the authority to conduct auditing and to sign auditing reports. Therefore, auditors who 
do not yet have a CPA license are assistant auditors. Moreover, not only auditors can have a CPA license but also significant researchers, trainers, or consultants. As shown in Table 1, $54.55 \%$ of the interviewees of this sample (24/44 interviewees) had this certificate. Notably, the number of persons who had a CPA license for more than 5 years was nearly $62.5 \%(15 / 24$ interviewees) and this reflected that the majority of interviewees were knowledgeable of the accounting field.

As such, this section introduced the general background of the professional accounting group outside of Vietnamese enterprises. Especially, this section described the characteristics of the interviewees in this group, including occupation, work experience, work area related to intangible assets, and the length of having a CPA license. Thus, before presenting the views of this group about intangible accounting practices in Vietnam, this study will summarize the accounting regulations for intangible assets in Vietnam in the next section.

\section{Concerning the accounting regulations for intangible assets in Vietnam}

To date, in Vietnam, accounting practices on intangible assets have mainly applied VAS 04 "Intangible assets", Circular No. 45/2013/TTBTC "Guiding regulations on the management, use, and depreciation of fixed assets" (dated April 25, 2013), and Circular No. 200/2014/TT-
BTC "Accounting regime of enterprises" (dated December 22, 2014). Intangible assets are assets that have no physical form, but a value can be determined, held, and used by an enterprise in production, business, service provision, or leasing in conformity with the recognition criteria of intangible assets (MOF, 2001). This standard also stipulates that the asset details required to be recognized as intangible assets must simultaneously satisfy the following five criteria: the definition of an intangible asset; acquisition of future economic benefits from the use of such assets; the initial value of the assets determined on a reliable basis; a useful life estimated greater than one year; and qualification in terms of value under the current regulations (MOF, 2001). However, the initial minimum value of the intangible asset is adjusted by other financial regulations of each period as presented in Table 2.

In Vietnam, intangible assets are reportedly only contained within physical objects such as compact discs and legal documents. Hence, they must be separately identifiable so that they can be clearly distinguished from goodwill (MOF, 2001). Goodwill arising from the enterprise merger of re-purchasing character is shown with a payment made by the asset purchaser to possibly obtain future economic benefits. Hence, presently, goodwill is being presented on the balance sheet and is being adjusted by the guidelines of VAS 11, Business Combinations.

Table 2. The initial minimum value of an intangible asset from 1986 to now

\begin{tabular}{|c|c|c|c|}
\hline Issued date & Issued financial regulation & $\begin{array}{l}\text { Initial minimum value of } \\
\text { intangible asset (VND) }\end{array}$ & $\begin{array}{l}\text { Exchange rate } \\
\text { (VND/USD) }\end{array}$ \\
\hline July 22, 1986 & Decision No. 507/-TC/DTXD (MOF, 1986) & 10,000 & 3,000 \\
\hline July 31, 1990 & $\begin{array}{l}\text { Circular No. 33-TC/CN } \\
\text { (MOF, 1990) }\end{array}$ & 500,000 & 5,000 \\
\hline December 30, 1999 & $\begin{array}{l}\text { Decision No. 166/1999/QD-BTC (MOF, } \\
\text { 1999) }\end{array}$ & $5,000,000$ & 13,921 \\
\hline December 12, 2003 & $\begin{array}{l}\text { Decision No. 206/2003/QD-BTC (MOF, } \\
\text { 2003) }\end{array}$ & $10,000,000$ & 15,463 \\
\hline October 20, 2009 & $\begin{array}{l}\text { Circular No. 203/2009/TT-BTC (MOF, } \\
\text { 2009) }\end{array}$ & $10,000,000$ & 17,852 \\
\hline April 25, 2013 & Circular No. 45/2013/TT-BTC (MOF, 2013) & $30,000,000$ & 20,960 \\
\hline
\end{tabular}

Note: Exchange rate obtained from Vietcombank (2020). 
Goodwill generated within the enterprise is not recognized as an intangible asset, because the goodwill is not an identifiable resource (MOF, 2001). In addition, internally generated intangible assets within enterprises only comprise assets for which enterprises can divide the asset-forming process into research and development (MOF, 2001).

After initial recognition, an intangible asset shall be determined according to historical costs, accumulated amortization, and residual value (MOF, 2001). Notably, VAS 04 does not mention recording the impairment of intangible assets (MOF, 2001).

Residual value in accounting books of intangibke assets

$=$ Historical cost (initial value)

- Accumulated amortization

The amortizable amount of an intangible asset with a finite useful life is allocated on a systematic basis over its useful life (MOF, 2001 $\&$ 2013). Amortization begins when the asset is available for utilization. The amortization cost for each period must be recognized as a production cost and a business expense. There are three amortization methods: straight-line, diminishing-balance, and units-of-production. Monthly average amortization equals the yearly amortization divided by 12 months.

With straight-line amortization, the annual amortized amount remains unchanged throughout the intangible asset's useful life. The annual average amortization for an intangible asset is calculated using the following formula:

$$
\begin{aligned}
& \text { Annual average amortization for an intangible asset } \\
& \qquad=\frac{\text { Initial value of the intangible asset }}{\text { Time of amortization }}
\end{aligned}
$$

In the above formula, the initial value of the intangible asset is the total cost borne by the enterprise to have the intangible asset until it is ready for utilization. The time of amortization is the time necessary for the enterprise to amortize the intangible asset to receive the capital investment beforehand. Typically, for intangible assets, the time of amortization equals the time of useful life.

For the diminishing-balance amortization method, the annual amortized amount gradually declines throughout the intangible asset's useful life. The annual amortization of an intangible asset is computed with the following formulae:

Annual amortization of an intangible asset $=$

Residual value of the intangible asset $\times$ Accelerated amortization rate

Accelerated amortization rate $=$

Rate of amortization by the straight - line method $\times$ Adjustment coefficient

Rate of amortization by the straight - line method $=\frac{1}{\text { Time of amortization of the intangible asset }}$

The adjustment coefficient is decided by the time of amortization of the intangible asset, as shown in Table 3.

The units of production are based on the estimated total quantity of products that the asset will create. Hence, the monthly amortization of the intangible asset under the units-ofproduction method will be equaled:

Monthly amortization of the intangible asset

$=$ Amount of products made monthly

$\times$ Average amortization for a unit of product

Average amortization for a unit of product

$$
=\frac{\text { Initial value of the intangible asset }}{\text { Output by design capacity }}
$$

Annual amortization

$=$ Amount of products made yearly

$\times$ Average amortization for a unit of product

Concerning the amortization time of intangible assets, enterprises self-determine their useful period without exceeding 20 years (MOF, $2001 \& 2013)$. In some cases, the useful life of

Table 3. Adjustment coefficients of the diminishing-balance amortization method

\begin{tabular}{lc}
\multicolumn{1}{c}{ Time of amortization of an intangible asset } & Adjustment coefficient (times) \\
\hline Up to 4 years & 1.5 \\
Over 4 to 6 years & 2 \\
Over 6 years & 2.5 \\
\hline
\end{tabular}


an intangible asset may exceed 20 years. However, enterprises must show reliable specific evidence in their financial statements. Particularly, for land use rights, amortization time equals the permitted time of the land use right. For copyright and patents, the amortization time is the protected duration indicated on the certificate of protection, excluding extended durations. For computer software and other intangible assets that become technically obsolete rapidly, their useful life is often shorter. Notably, the period and amortization methods of intangible assets must be reconsidered at least fiscally. The amortization methods of intangible assets may be changed when businesses present a significant change in their manner of estimating economic benefits to be recoverable for the enterprise.

Views of the professional accounting group about intangible assets accounting in Vietnam

The obstacles of intangible assets
accounting

For the professional accounting sector, the skills and knowledge of accounting staff about intangible assets accounting were reported as the biggest current matter of enterprises. Notably, there were 36/44 interviewees who agreed with this perspective. Some interviewees said that disclosed intangible assets accounting information was sometimes incomplete and unclear. Besides this, the accounting legal framework was determined to be one of the current disadvantages along with the skills and knowledge of accountants. Specifically, the delay in updating the accounting legal framework and poor converging with IAS/IFRS were the main problems. Simultaneously, the negative points related to a manager's knowledge, internal regulations, and business characteristics also had significant influence on intangible assets accounting (more than 50\%).

In addition, this study assessed the identified obstacles of intangible assets accounting in Vietnamese enterprises through a five-point Likert scale in Table 4. The rating assessment options chosen were: A0 - not at all serious, A1 slightly serious, A2 - somewhat serious, A3 moderately serious, and A4 - extremely serious.

Accounting staff's skills and knowledge are the most current weaknesses of intangible assets accounting

Notably, in accordance with the interviewees' perspectives, when accountants practiced intangible assets accounting, the issues related to the skills and knowledge of the accountants were mentioned. Simultaneously, interviewees assessed "How often did the issue occur in intangible assets accounting?" through a five-point Likert scale (0 - Never, 1 - Rarely, 2 Sometimes, 3 - Often, and 4 - Always) in Table 5. As such, these issues reflect the low quality of accountants in intangible assets accounting practices of Vietnamese enterprises. The reason is that accountants do not yet clearly understand the accounting guidelines about intangible assets accounting. This is why intangible assets accounting information was sometimes disclosed as being incomplete, faithless, and unclear.

Table 4. The obstacles of intangible assets accounting

\begin{tabular}{|c|c|c|c|c|c|c|c|}
\hline \multirow{2}{*}{ Item } & \multirow{2}{*}{$\begin{array}{l}\text { Frequency } \\
(\mathrm{N}=44)\end{array}$} & \multirow{2}{*}{$\begin{array}{c}\text { Percentage }\left({ }^{*}\right) \\
(\%)\end{array}$} & \multicolumn{5}{|c|}{ Assessment of these identified obstacles } \\
\hline & & & $\mathrm{A} 0$ & $\mathrm{~A} 1$ & $\mathrm{~A} 2$ & A3 & A4 \\
\hline 1. Internal control regulations & 32 & 72.73 & 12 & 3 & 5 & 10 & 14 \\
\hline 2. Accounting legal framework & 32 & 72.73 & 12 & 5 & 6 & 9 & 12 \\
\hline 3. Skills and knowledge of accountants & 36 & 81.82 & 8 & 2 & 8 & 11 & 15 \\
\hline 4. Knowledge of managers & 27 & 61.36 & 17 & 6 & 3 & 13 & 5 \\
\hline 5. Business characteristics & 24 & 54.55 & 20 & 4 & 7 & 10 & 3 \\
\hline
\end{tabular}

Note: $\left({ }^{*}\right)$ Calculated based on the multiple-choice observations of the total sample (44 interviewees); A0: not at all serious, A1: slightly serious, A2: somewhat serious, A3: moderately serious, and A4: extremely serious 
Table 5. Issues in the skills and knowledge of accountants and the frequency of occurrence

\begin{tabular}{|c|c|c|c|c|c|}
\hline Types of Issue & $\begin{array}{c}0 \\
\text { Never }\end{array}$ & $\begin{array}{c}1 \\
\text { Rarely }\end{array}$ & $\begin{array}{c}2 \\
\text { Sometimes }\end{array}$ & $\begin{array}{c}3 \\
\text { Often }\end{array}$ & $\begin{array}{c}4 \\
\text { Always }\end{array}$ \\
\hline $\begin{array}{l}\text { (1) Intangible assets management is not tight enough, for example, } \\
\text { intangible assets records are incomplete; intangible assets have not } \\
\text { yet been transferred to enterprises but recorded on a balance sheet; } \\
\text { there is no ledger or detailed cards for each intangible asset; }\end{array}$ & 8 & 2 & 8 & 15 & 11 \\
\hline $\begin{array}{l}\text { (2) For intangible assets coming from received capital contributions, } \\
\text { sometimes accountants forget to re-register the ownership certificate } \\
\text { for the asset which needs ownership registration; }\end{array}$ & 8 & 5 & 11 & 14 & 6 \\
\hline $\begin{array}{l}\text { (3) Not accurately identifying what is an intangible asset of } \\
\text { enterprises such as land rent paid in a lump sum for the whole lease } \\
\text { term, cost of compensation and site clearance, cost in the research } \\
\text { phase, establishment enterprise costs, and so on are still recorded } \\
\text { as intangible assets; }\end{array}$ & 8 & 3 & 7 & 11 & 15 \\
\hline $\begin{array}{l}\text { (4) The amortization method of intangible assets is not registered } \\
\text { with the local tax authority; }\end{array}$ & 8 & 4 & 9 & 16 & 7 \\
\hline $\begin{array}{l}\text { (5) The point of amortization time is not correct. Especially, some } \\
\text { accountants still amortized intangible assets based on the round- } \\
\text { month principle. According to the regulations, the point of } \\
\text { amortization time is the time when the asset is ready to be used. } \\
\text { Currently, amortization in accordance with round-day principle is } \\
\text { being utilized; }\end{array}$ & 8 & 4 & 9 & 16 & 7 \\
\hline $\begin{array}{l}\text { (6) The upgrade of intangible assets has finished but accountants } \\
\text { have not yet recorded an increase of the historical cost of the } \\
\text { intangible assets, re-evaluated the useful period, and adjusted the } \\
\text { amortization value into the expenses during the period; }\end{array}$ & 8 & 3 & 10 & 15 & 8 \\
\hline $\begin{array}{l}\text { (7) Sometimes there is no distinction between large repairs and } \\
\text { upgrades; }\end{array}$ & 8 & 3 & 10 & 15 & 8 \\
\hline $\begin{array}{l}\text { (8) The intangible asset has expired but has not yet been fully } \\
\text { amortized. The unallocated value of an intangible asset was not } \\
\text { record into the expenses in the period; }\end{array}$ & 8 & 7 & 17 & 8 & 4 \\
\hline $\begin{array}{l}\text { (9) Some accountants continue to amortize intangible assets that } \\
\text { have been fully amortized and are still in use; }\end{array}$ & 8 & 9 & 13 & 8 & 6 \\
\hline $\begin{array}{l}\text { (10) Failing to fully implement the intangible asset liquidation } \\
\text { procedures such as setting up the liquidation council of an intangible } \\
\text { asset, a liquidation decision, no liquidation minutes, forgetting to } \\
\text { issue an invoice for liquidation assets, etc.; }\end{array}$ & 8 & 11 & 9 & 13 & 3 \\
\hline $\begin{array}{l}\text { (11) Sometimes, the inventory reports of intangible assets at the end } \\
\text { of a financial year do not classify unused intangible assets, those } \\
\text { awaiting liquidation, and fully amortized intangible assets. The } \\
\text { differences between ledger and inventory records has not yet been } \\
\text { processed. }\end{array}$ & 8 & 10 & 13 & 8 & 5 \\
\hline
\end{tabular}

System of current accounting regulations for intangible assets is not yet integrated with IAS/IFRS

Based on the results of the survey, the delay in updating the accounting legal framework and poor converging with IAS/IFRS were the main problems. Especially, the opinions of the interviewees in professional accounting sectors are described in detail, as follows:

Case 1 - Accounting Law:
The National Assembly (2015) issued Accounting Law No. 88/2015/QH13 (Accounting Law 2015), which became effective on January 1, 2017, to supersede Accounting Law 2003. Although Accounting Law 2015 mentions the fair value concept, which is a major change in accounting principles ( $\mathrm{PwC}, 2016)$, to date, there are not yet any new detailed guidelines to apply this principle to enterprises. This mention just stops short of providing general guidelines. Especially, Accounting Law 2015 indicates that assets and liabilities must be 
revaluated at fair value at the financial reporting date. Financial instruments must be measured at fair value; monetary items denominated in foreign currencies are measured at actual exchange rates and assets or liabilities which have frequent volatility in value are revaluated at fair value. However, the fair value revaluation of assets and liabilities must be based on reliable measurements (such as the three levels of inputs in IFRS 13). If there are no reliable measurements, the assets and liabilities are measured at historical cost. That is why the interviewees indicated that until now, the cost model is still being chosen to be used in intangible assets accounting. However, the cost model in the case of Vietnamese enterprises did not include accumulated impairment. Hence, the accounting information of intangible assets is not yet exact and is incomplete.

\section{Case 2 - VAS 04 - Intangible Assets:}

This standard was enacted in 2001 based on the first version of IAS 38 and Vietnamese economic conditions at that time. To date, the contents of VAS 04 have been neither updated nor amended. Based on this standard, after initial recognition, only a cost model without impairment loss is chosen to record the value of intangible assets. In addition, indefinite intangible assets are not amortized and are not impaired annually. Thus, the value of intangible assets is recorded exactly and faithlessly.

Case 3 - accounting policies and accounting circulars:

Both accounting policies and accounting circulars were enacted in accordance with accounting law and the VAS system. All accountants in Vietnamese enterprises have performed accounting practices based on the guidelines of accounting policies and accounting circulars. The accountants have depended on these guidelines so much and their creativity is very low.

For intangible assets accounting, the interviewees said that the accounting guidelines about the amortization period are quite wide. This issue is difficult for accountants when they choose the exact amortization period for an intangible asset. In reality, the same kinds of intangible assets have different amortization periods among enterprises. Moreover, both accounting policies and accounting circulars have not yet mentioned recording the impairment of intangible assets or fair value.

In conclusion, according to the interviewees' perspectives, the system of current accounting regulations for intangible assets is not yet integrated with IAS/IFRS. This is a disadvantage for the Vietnamese accounting system and accounting practices in Vietnamese enterprises.

\section{Limited knowledge of managers and internal governance}

According to the interviewees' views in the professional accounting sector group, $27.28 \%$ of the interviewees (12/44 respondents) believed that the internal regulation system for intangible assets operates well, meanwhile, $18.18 \%$ of the interviewees (8/44 respondents) said that this system has not yet been established. Additionally, 54.54\% of the respondents (24/44 respondents) answered that the internal regulation system for this asset has partially satisfied appropriation of the demand of internal governance for intangible assets accounting. Especially, the internal control regulations depended on the accounting legal framework too much. In addition, some business managers or directors thought their business can run well without the internal control regulations for intangible assets. Therefore, interviewees mentioned that the limited knowledge level of both managers and accounting staff has been the key reason for weakness about internal control regulations in Vietnamese enterprises.

The results of the professional accounting sector group's assessment of the internal control regulation system for intangible assets of enterprises is shown in Table 6.

In conclusion, the three main obstacles in intangible assets accounting were identified as (1) lack of accounting staffs' skills and knowledge, (2) the system of current accounting regulations for intangible assets is not yet integrated with IAS/IFRS, and (3) the limited knowledge of managers and internal governance. 
Table 6. The assessment of interviewees about the internal regulation system for intangible assets in Vietnamese enterprises

\begin{tabular}{|c|c|c|}
\hline Criteria & $\begin{array}{l}\text { Frequency }{ }^{(1)} \\
\qquad(\mathrm{N}=44)\end{array}$ & Percentage $^{(2)}(\%)$ \\
\hline \multicolumn{3}{|l|}{ General assessment } \\
\hline - No internal regulations & 8 & 18.18 \\
\hline - Partial appropriate regulations & 24 & 54.54 \\
\hline - Good internal regulations & 12 & 27.28 \\
\hline \multicolumn{3}{|l|}{ Detailed assessment } \\
\hline $\begin{array}{l}\text { 1. Apply the principle of responsibility classification among functions such as } \\
\text { maintaining and protecting intangible assets, recording on a ledger, approving } \\
\text { purchasing, liquidating, and selling intangible assets. }\end{array}$ & 30 & 68.18 \\
\hline $\begin{array}{l}\text { 2. Set up a plan and estimate demand using intangible assets for the next financial } \\
\text { year. }\end{array}$ & 31 & 70.45 \\
\hline \multicolumn{3}{|l|}{ 3. Other internal regulation tools, as follows: } \\
\hline $\begin{array}{l}\text { 3.1. Accounting book system for intangible assets: enterprises need to open detailed } \\
\text { books, detailed cards, and detailed records for each type of intangible asset; }\end{array}$ & 33 & 72.73 \\
\hline 3.2. Procedures to purchase new intangible assets; & 25 & 56.82 \\
\hline 3.3. Procedures of liquidating an intangible asset; & 25 & 56.82 \\
\hline $\begin{array}{l}\text { 3.4. Regulations to distinguish expenses that were added into the initial value of an } \\
\text { intangible asset or were added as operation expenses in the financial year; }\end{array}$ & 28 & 63.64 \\
\hline $\begin{array}{l}\text { 3.5. Regulations for the protection of intangible assets such as methods to prevent stealing } \\
\text { and fire, buying insurance against fire, etc.; }\end{array}$ & 25 & 56.82 \\
\hline $\begin{array}{l}\text { 3.6. Regulations relative to the amortization of intangible assets such as the } \\
\text { amortization method and amortization period. }\end{array}$ & 30 & 65.91 \\
\hline
\end{tabular}

Note: (1) Number of interviewees who cited that the internal regulations for intangible assets in enterprises satisfied these criteria (2) Calculated based on the multiple-choice observations of the total sample (44 interviewees).

\section{Policy implications}

Based on these findings, this study will give some suggestions to improve the current situation of intangible assets accounting practices in Vietnam, as follows:

\section{Continuous renovations of the VAS system and regulations related to standards to integrate with the IAS/IFRS system}

After a long time since the first promulgation, the VAS system has not yet been amended. Therefore, the majority of interviewees supported the idea of adjusting and amending the accounting system in accordance with the new version of the IAS/IFRS system. This idea is the foremost solution for the Vietnamese accounting system at this time. Related to the accounting of intangible assets, the idea of renewing VAS 04 based on the latest version of IAS 38 and the conditions of the Vietnamese economy should be also considered.
In addition, the promulgation of accounting standards for the impairment of assets in accordance with IAS 36 and the conditions of the Vietnamese economy should also be applied.

\section{The MOF should strengthen training about the new IAS/IFRS}

To achieve the aims of the program "Vietnam accounting and auditing strategy to 2020, vision 2030" (Decision No. 480/QD-TTg, dated March 18, 2013), in recent years, the MOF has organized successful IFRS/IAS training sessions with the participation of officers from Deloitte, KPMG, Ernst \& Young, and the Association of Chartered Certified Accountants (ACCA) of Vietnam. However, these training courses were only organized in Hanoi and Ho Chi Minh City, hence, it was difficult for lecturers, researchers, and accounting staff who were located in other cities to participate. This is an example of one of the difficulties to disseminate the content of IAS/IFRS. To 
improve this issue, the MOF should organize training courses in at least three cities like Hanoi, Danang, and Ho Chi Minh City, which are representative of the three regions of Vietnam, namely, Northern Vietnam, Central Vietnam, and Southern Vietnam, respectively.

Additionally, currently, the contents of the training sessions often focus on the academic contents of IAS/IFRS. This means that the practices or applications of IAS/IFRS are limited, which will lead to unclear understanding of the learners and low effectiveness of these courses. Therefore, the MOF should give detailed examples during discussions that are relevant to the contents of IAS/IFRS to clearly explain the contents of IAS/IFRS.

\section{Enhance the role of universities, academies, and institutes in the transmission of contents related to the accounting standards}

To date, undergraduate courses for accounting at Vietnamese universities and academies often emphasize accounting regulations in accordance with the contents of circulars. Currently, accounting programs for undergraduate students often focus on research about two circulars, namely Circular No. 200/2014/TT-BTC (Accounting regime) and Circular No. 133/2016/TT-BTC (Accounting regime for SMEs). In addition, the contents of the accounting standards are rarely mentioned in undergraduate courses. This is a disadvantageous point of the current system. Therefore, universities and academies should include the contents of VAS, IAS, and IFRS in the accounting training courses to improve the quality of accountants.

Moreover, universities and academies should cooperate with the ACCA of Vietnam in the accounting training process. This cooperation would help and orient students to develop their accounting profession towards international integration. This would be an opportunity for students to become Chartered Certified Accountants from the ACCA and afterwards, these students could work as accountants in any enterprise in the world. In addition, based on this platform, they would be active to update new accounting standards and especially, this would help to improve the quality of Vietnamese accountants in the future.

\section{Set up more effective internal regulations}

Depending on the situation of each enterprise, the content of internal regulations should be detailed or unified for all entities of the whole group. Thus, more details about the accounting methods, measurement, and recognition of intangible assets would make compliance easier. The basic contents of the internal regulations should follow the current legal system and business characteristics of enterprises about the forms of accounting documents, the types of documents, and the measurement, recognition, and accounting methods.

\section{Conclusions}

This study described the characteristics of members of a professional accounting group, including work positions, educational levels, and work experience. This group consisted of 44 interviewees who were auditors, lecturers, and banking staff, among others. Simultaneously, this study analyzed accounting regulations for intangible assets in Vietnam. Especially, this study indicated the views of the professional accounting group about intangible assets accounting in Vietnam based on the results of the survey. Particularly, there are some obstacles in intangible assets accounting practices. Firstly, the accounting staff's skills and knowledge are the most current weaknesses of intangible assets accounting. In addition, the system of current accounting regulations for intangible assets is not yet integrated with IAS/IFRS. Lastly, the limited knowledge of managers and internal governance are weak points. Thus, the improvement of accounting regime documents for intangible assets and the application of solutions to overcome the shortcomings in intangible asset accounting practices in enterprises is very necessary. Particularly, to innovate intangible assets accounting in Vietnam, some policy implications should be implemented, such as, (i) continuous renovation of the VAS system and regulations related to standards to integrate with 
the IAS/IFRS system, (ii) the MOF should strengthen its training programs about the new IAS/IFRS, (iii) enhance the role of universities, academies, and institutes in the transmission of accounting standards contents, and (iv) set up more effective internal regulations. Additionally, small specialized discussions among accountants, lecturers, auditors, and others in one city should be encouraged to be more open as these are an opportunities for participants to share their accounting experience.

\section{Acknowledgments}

This work was financially supported by Komazawa University, Japan, and the International Cooperation Department, Ministry of Education and Training in Vietnam.

\section{References}

Becerra-Fernandez I. \& Sabherwal R. (2015). Knowledge management: Systems and processes (2nd ed.). Routledge. Taylor \& Francis. New York \& London.

Brand Finance (2016). The Brand Finance Top 50 Vietnam Brands Report 2016 on Vietnam's intangible assets and brands. Retrieved from http://brandfinance.com/images/upload/20160911_bf _vietnam_2016_en.pdf on November 12, 2020.

Derun I. (2013). The essence of intellectual capital in economics and accounting. Management Theory and Studies for Rural Business and Infrastructure Development, Scientific Journal. 35(4): 498-511.

Goldfinger C. (1998). Understanding and measuring the intangible economy: Current status and suggetstions for future research. The 23rd CIRET conference (CIRET Conference Proceedings). November 1, 1998. Helsinki. Finland: 1-22.

Hall R. (2001). The Stock Market and Capital Accumulation. Retrieved from https://web.stanford.edu/ rehall/SMCA-AER-Dec2001.pdf on November 12, 2020.

IASB (International Accounting Standards Board) (2014b). International Accounting Standard No. 38 (IAS 38) Intangible Assets. Retrieved from https://www.ifrs.org/issued-standards/list-ofstandards/ias-38-intangible-assets/\#about November 12, 2020

Liselotth A. \& Carolina M. (2006). Accounting for Intangible Assets - Relevance Lost?, Bachelor Thesis. School of Business Economics and Law, Gõteborg University: 6-7.

Mention A. L. (2012). Intellectual Capital, Innovation and
Performance: A Systematic Review of the Literature. Business and Economic Research. 2(1): 1-37. DOI:10.5296/ber.v2i1.1937.

MOF (Ministry of Finance) (1986). Decision No. 507/TC/DTXD dated July 22, 1986 on promulgating the regimes of management and depreciation of fixed assets. Retrieved from https://thuvienphapluat.vn/vanban/Tai-chinh-nha-nuoc/Quyet-dinh-507-TC-DTXDChe-do-quan-ly-khau-hao-tai-san-co-dinh-37138.aspx on November 12, 2020 (in Vietnamese).

MOF (Ministry of Finance) (1990). Circular No. 33-TC/CN dated July 31, 1990 on promulgation of the regime of management, utilization and depreciation of fixed assets. Retrieved from https://thuvienphapluat.vn/vanban/Ke-toan-Kiem-toan/Thong-tu-33-TC-CN-che-dokhau-hao-tai-san-co-dinh-42196.aspx on November 12, 2020 (in Vietnamese).

MOF (Ministry of Finance) (1999). Decision No. 166/1999/QD-BTC dated December 30, 1999 on promulgation of the regime of management, utilization and depreciation of fixed assets. Retrieved from https://thuvienphapluat.vn/van-ban/doanhnghiep/quyet-dinh-166-1999-qd-btc-che-do-quan-lysu-dung-trich-khau-hao-tai-san-co-dinh46055. aspx? $\mathrm{v}=\mathrm{d}$ on November 12, 2020 (in Vietnamese).

MOF (Ministry of Finance) (2001). Vietnamese Accounting Standard No. 04 - Intangible Assets. Retrieved from https://thuvienphapluat.vn/van-ban/Ke-toan-Kiemtoan/Quyet-dinh-149-2001-QD-BTC-bon-04-chuanmuc-ke-toan-Viet-Nam-dot-1-Hang-ton-khoTai-sanco-dinh-huu-hinh-vo-hinh-Doanh-thu-nhap-khac48964.aspx on November 12, 2020 (in Vietnamese).

MOF (Ministry of Finance) (2003). Decision No. 206/2003/QD-BTC dated December 12, 2003 on promulgation of the regime of management, utilization and depreciation of fixed assets. Retrieved from https://thuvienphapluat.vn/van-ban/ke-toan-kiemtoan/quyet-dinh-206-2003-qd-btc-che-do-quan-ly-sudung-trich-khau-hao-tai-san-co-dinh-51743.aspx?v=d on November 12, 2020 (in Vietnamese).

MOF (Ministry of Finance) (2009). Circular No. 203/2009/TT-BTC dated October 20, 2009 on guiding the regime of management, utilization and depreciation of fixed assets. Retrieved from https://thuvienphapluat.vn/van-ban/Ke-toan-Kiemtoan/Thong-tu-203-2009-TT-BTC-huong-dan-che-doquan-ly-su-dung-trich-khau-hao-tai-san-co-dinh97013.aspx on November 12, 2020 (in Vietnamese).

MOF (Ministry of Finance) (2013). Circular No. 45/2013/TT-BTC dated April 25, 2013 on guiding the regime of management, utilization and depreciation of fixed assets. Retrieved from https://thuvienphapluat.vn/van-ban/Doanhnghiep/Thong-tu-45-2013-TT-BTC-Che-do-quan-lysu-dung-va-trich-khau-hao-tai-san-co-dinh183508.aspx on November 12, 2020 (in Vietnamese). MOF (Ministry of Finance) (2014). Circular No. 
200/2014/TT-BTC dated December 22, 2014 on guidelines for accounting policies for enterprises. Retrieved from https://thuvienphapluat.vn/vanban/Doanh-nghiep/Thong-tu-200-2014-TT-BTChuong-dan-Che-do-ke-toan-Doanh-nghiep263599.aspx on November 12, 2020 (in Vietnamese).

PwC (2016). Accounting Law 2015. PwC Vietnam NewsBrief. Retrieved from https://www.pwc.com/vn/en/publications/2016/pwcvietnam-newsbrief-accounting-law-2015-en.pdf on November 12, 2020.

Roslender R. \& Fincham R. (2004). Intellectual capital accounting in the UK: A field study perspective.
Accounting, Audting and Accountability Journal. 17(2): 178-209.

The European Union (2002). Guidelines for managing and reporting on intangibles. Meritum Project. Retrieved from

https://cristinachaminade.files.wordpress.com/2018/0 7/meritum-guidelines.pdf on November 12, 2020.

The National Assembly (2015). Accounting Law No. 88/2015/QH13: Accounting Law dated November 30, 2015 (in Vietnamese).

Vietcombank (2020). Exchange rate. Retrieved from https://www.vietcombank.com.vn/exchangerates/ on November 12, 2020 